\title{
Finding a Career that Fits Your Personality
}

\author{
Nahla Aljojo \\ Faculty of Computing and \\ Information Technology, \\ Information System \\ Department, King AbdulAziz \\ University \\ Jeddah, Saudi Arabia \\ Najla Saeed Jarad \\ Faculty of Computing and \\ Information Technology, \\ Information System Department \\ King AbdulAziz University \\ Jeddah, Saudi Arabia
}

\author{
Huda Saifuddin \\ Arts and Humanities College, \\ Cognitive Psychology \\ Department, King AbdulAziz \\ University \\ Makkah, Saudi Arabia
}

\author{
Reem Zahir Althagfi \\ Faculty of Computing and \\ Information Technology, \\ Information System Department \\ King AbdulAziz University \\ Jeddah, Saudi Arabia
}

\author{
Areej Alshamasi \\ Faculty of Economics and \\ Administration, Public \\ Administration Department, \\ King Abdulaziz University \\ Jeddah, Saudi Arabia
}
Shahrazad Mustafa Mdani
Faculty of Computing and Information Technology, Information System Department
King AbdulAziz University Jeddah, Saudi Arabia

\begin{abstract}
Many students have problems determining their college majors and what their suitable career could be. This paper shows how to find a career that fits their personality, and aims to help students to analyse their personality based on yes/no questions. This paper will extract the best suitable career for them by using the Holland test - the Arabic version - that is one of the most popular models used for career tests. The Holland theory groups people into six different categories of personality type known as (RIASEC): Realistic (R), Investigative (I), Artistic (A), Social (S), Enterprising (E), and Conventional (C) ,This study implements a new set of tasks, testing fifty-five students in King Abdul Aziz University with the use of the Arabic version of the Holland test. The test was applied to females students from two majors. The implications of the test results will help students know their personality types and determine the suitable career for them, with the results suggesting what the suitable career is for students that match their personalities. The authors provide a review of previous studies and a description of the approach that the authors followed. This paper compares females students majoring in computer science and information systems at King Abdul Aziz University, with the result showing a difference between the two majors.
\end{abstract}

\section{Keywords}

Holland's RIASEC types, interests, personality, the career key, professional orientation

\section{INTRODUCTION}

Finding a career that fits your personality is an Arabic smart system, and reflects the wise vision of the people's choices that can be very helpful for future careers. Finding career that fits your personality (FCFP) works to attract every person who needs advice in making their decision, and brings hope to their employment field by experiencing the test based on trying to understand the student's career aims in social responsibility, cooperation and to provide benefit to society. Self-selection decisions which students actively search for and select situations that encourage them to create their trademark investments in the future aid their capacity to enter and be effective in their chosen career fields [1].
This self-selection assumption in instructive settings leaves Holland's (1997) declarations that people favour situations or circumstances in which they can participate in the exercises, parts, capabilities, and diversions that parallel their type of identity, and that individuals will maintain a strategic distance from circumstances that are incongruent with their identity type [1].

Frank Parsons is regarded the father of vocational guidance and gave an influential lecture on this area when he produced a paper of advice which helped advise eighty people who had asked for assistance. He is seen as the developer of vocational advice and formed a method based on skills matching that was subsequently adapted into the trait and factor theory of occupational choice [2]. Seven Stages of Trait and Factory Theory as the following:

1. Personal data: gather information about the person and know the career problem [2]

2. Self-analysis: the examination should be individual and private with the counsellor and should be recorded preference and interest that effect on the choice of work [2].

3. The client's own choice and decision: the client should be made the choice of vocation and the counsellor should be a guide [2].

4. Counsellor's analysis: the counsellor tests client if he/she select the right career path ([2]

5. Outlook on the vocational field: the counsellor should know about industrial knowledge and types of career jobs, positions, in addition to locations of training [2]

6. Induction and advice: wise advices that provide by counsellor are important at this stage [2].

7. General helpfulness: the counsellor helps the client to fit into the chosen work [2].

The result of Trait and factor theory is remaining since the beginning of theory until now the most famous theory is inspired and used "Trait and factor theory" is "Strong Interest Inventory" [3]. 
The (MBTI) assessment is a psychological questionnaire designed to measure psychological thinking in how people understand the world and make decisions (Myers \& Myers, 1995). However, the questions in this all address four main measurements of personality types and their opposite - E-I, $\mathrm{S}-\mathrm{N}, \mathrm{T}-\mathrm{F}$, and J-P [4], the types are explained as follows: Extroverted-introverted (EI), sensing-intuitive intuition (SN), thinking-feeling (TF) and judging-perceiving (JP). Nursing students demonstrate a preference for extrovert over introvert, sensing over intuition, feeling over thinking, and judging over perceiving. The significance of finding students in all sixteen personality type categories is ESFJ, ESTJ, ISTJ, and ENFJ [5].

According the Roe's hypothesis there are two straightforward approaches both to and from people founded on the association between profession and individual characteristics, and which was founded on her analyses of renowned artists and scientists. Roe suggested, too, that these two ways are connected to events as children, so for example a child who had receptive parents would like a career focused on human interaction whereas one who had less welcoming parentage would like to work on their own [6].

The Herrmann brain dominance instrument (HBDI) is the evaluation of brain thinking methodology. Herrmann identifies four different modes of thinking - analytical thinking, sequential thinking, interpersonal thinking, and imaginative thinking [7] and [8]

The study focuses on thinking styles of students in Jordan using Herrmann's whole brain model. No serious critical differences were found between students' thinking styles, and this study means that students having a specific thinking style would not be hugely different from those with other thinking tests styles and shows no noticeable differences between students' thinking styles according to their gender. This study utilises Herrmann's theory and tests the brain thinking of undergraduate students to determine their preference, decision style and skills in order to both explore the suitable major subject and profession and to help educational planners expand the methodology when showing the educational subjects [9].

This paper has been designed to find a career that fits personality (FCFP). The Holland test was developed as a technique that can help to determine the suitable career according to the six aforementioned personality types. Furthermore, this paper compares computer science students' and information system students' personality types and the career that fits their personality within Jeddah.

The authors choose a different sample of females from King Abdul Aziz University, AL Faysalia branch (Faculty of Computing and Information Technology), and from computer science (CS) and information system (IS) majors to determine the suitable career according to the six personality types. The authors subjected them to a test including 106 questions, analysed and calculated the results manually, and showed that the most optimal solution is the Holland test system used by normal students to help them better understand their personality. The advantages of this solution are the time saved, effort and ease of use, and that it can be understood and used anytime or anywhere.

\section{HOLLAND OCCUPATIONAL THEMES (RIASEC)}

John Lewis Holland, Born in Omaha, Nebraska on October 21,1919 , was a psychologist who focused on personality and skills themes. John Holland's work has impacted the field of job guidance. The hypothesis and applications that have been created in the course of the last fifty years or so have produced a lot of examination and expert analysis. The goal is to understand both the state of this hypothesis at the start and its current status, and we distinguished the gathering of assets and gathered data from different styles in much of our research. This examination is to evaluate the state of Holland's hypothesis and its applications by checking the different models in analysis of his work since 1953 [10].

The theory of jobs introduced by Holland (1985), described a person's personality as being one of six main kinds. Holland suggests that most individuals in our society belong to one of six main kinds - realistic, conventional, enterprising, investigative, social and artistic. Alongside these types, one has a singular identity, for example this could be interests, values, abilities, or fantasies [11]

Moreover, Holland expounded his hypothesis and focused around his experience as an academic and jobs instructor. His experience allowed him to decide how people might be regrouped into different types focused on their profession; However, This methodology has created a relationship between different working environment settings, singular identities, and the career decision process and its advancement [12].

To sum up, Holland's codes, both individual and environmental, are communicated in three-letter codes. A three-letter code is making by selecting, from Holland's six main types, the three main types in the most suitable category for the selected person. The individual's work nature is based on the three-letter code and gives a short summary of what the person is good at by explaining the level of similarity to the three words together. For example, the three-letter code of CER proposes that the individual has an overwhelming conventional identity and additionally has characteristics of enterprise and realism [11]. The Six Holland types as the following:

1. Realistic (Adventuring/Producing): This person prefers manual occupations working with their hands, tools, machines, and technology and they have a narrow scope of interests with a much closed system of beliefs and values. In troubleshooting and problem solving they prefer practical and structured solutions [1].

2. Investigative (Analytic): These people prefer occupations that work with ideas, examination, watching, understanding and controlling processes. This type of person doesn't prefer social and business activities. In troubleshooting and problem solving they depend on thinking, collecting data, and making careful analyses [1].

3. Conventional (Organizing): These people prefer occupations that deal with data, ordering written or numerical data, organising things or performing systematic activities. This type of person doesn't prefer artistic, ambiguous, or exploratory tasks. In troubleshooting and problem solving they follow established rules and look for advice or counsel [1]. 
4. Artistic (Creative): prefer occupations that work with activities that are ambiguous, unsystematic, disordered or use materials to produce creative art. This type of person doesn't prefer systematic, orderly, or monotonous activities. In troubleshooting and problem solving they demonstrate inventive, creative and artistic competencies [1].

5. Enterprising (Influencing): These people prefer activities that control others in an attempt to reach organisational goals or achieve economic gain. This type of person doesn't prefer scientific and intellectual tasks [1].

6. Social (Helping): These people prefer activities that control others in an attempt to cure, teach, develop, or train them. This type of person doesn't prefer systematic, orderly, or monotonous activities. In troubleshooting and problem solving they show dominant human interaction and social competencies [1].

Since the idea of careers is basic to the personality, Holland created a group of six main personalities. See figure (1) which summaries the six types.

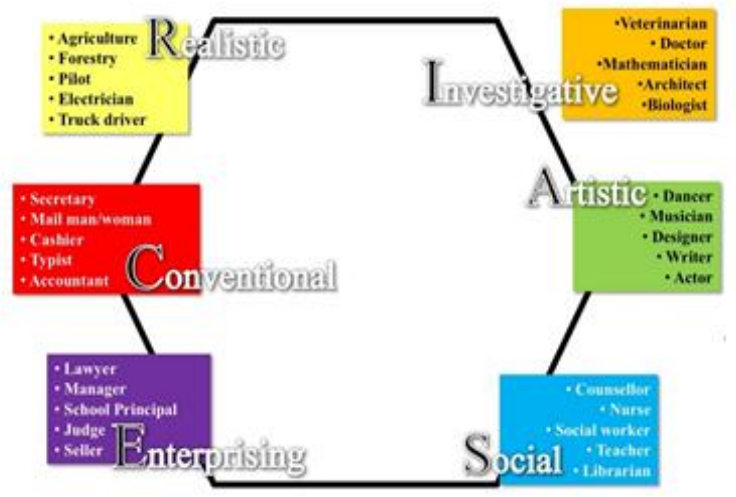

Figure .1: The Six Holland types

Table 1: The Questions of RIASEC

\begin{tabular}{|c|c|c|c|c|c|c|c|c|c|c|c|c|c|}
\hline \multirow{2}{*}{$\mathrm{R}$} & 3 & 8 & 10 & 15 & 26 & 31 & 36 & 37 & 42 & 45 & 54 & 65 & 82 \\
\hline & 85 & 96 & 99 & 100 & 101 & & & & & & & & \\
\hline \multirow{2}{*}{ I } & 13 & 16 & 18 & 19 & 25 & 29 & 43 & 44 & 48 & 50 & 52 & 60 & 66 \\
\hline & 73 & 76 & 77 & 93 & 98 & & & & & & & & \\
\hline \multirow{2}{*}{ A } & 1 & 4 & 14 & 17 & 32 & 33 & 35 & 40 & 47 & 49 & 58 & 68 & 80 \\
\hline & 81 & 90 & 91 & 102 & 105 & & & & & & & & \\
\hline \multirow{2}{*}{$\mathrm{s}$} & 5 & 6 & 7 & 22 & 23 & 28 & 46 & 59 & 62 & 63 & 64 & 67 & 72 \\
\hline & 78 & 84 & 88 & 94 & 104 & & & & & & & & \\
\hline \multirow[b]{2}{*}{$\mathrm{E}$} & 9 & 11 & 20 & 21 & 30 & 34 & 41 & 51 & 53 & 55 & 61 & 69 & 74 \\
\hline & 75 & 89 & 95 & 97 & 106 & & & & & & & & \\
\hline \multirow{2}{*}{ C } & 2 & 12 & 24 & 27 & 38 & 39 & 56 & 57 & 70 & 71 & 79 & 83 & 86 \\
\hline & 87 & 92 & 103 & & & & & & & & & & \\
\hline
\end{tabular}

\subsection{Procedure}

For every question, two answers either yes or no will show on the screen, the students will read the questions and select the answer that best describes them.

The Holland test consisted of three pages, the first page containing thirty-four questions and the second and third pages containing thirty-five questions. When a student enters the Holland test system, the first page will show up on the screen with two yes or no options, and the student must choose one answer for each question so they are able to move to the next page. After answering all thirty-four questions, this

\section{METHOD}

\subsection{Participants}

The total number of participants was fifty five females aged twenty to twenty-four years old. All participants are students from King Abdul-Aziz University (Faculty of Computing and Information Technology), with twenty-eight of them studying computer science majors and twenty-seven studying information system majors.

\subsection{Instruments}

The Holland test consisted of 106 questions, each question requiring a simple yes or no response, and each of the 18 questions belonging to one of the six personality types discussed above - Realistic (R), Investigative (I), Artistic (A), Social (S), Enterprising (E) - except conventional (C) which is featured in sixteen questions. Divided questions can be seen below (see Table 1). When showing all questions the students were given two possible answers - either yes or no - for each question action is repeated for the next two pages. All pages from sign up to receiving the final report and logging out will be explained below:

Sign up:

In this page, the user must complete the registration form and create an account before he or she starts the test (see Figure 2). 


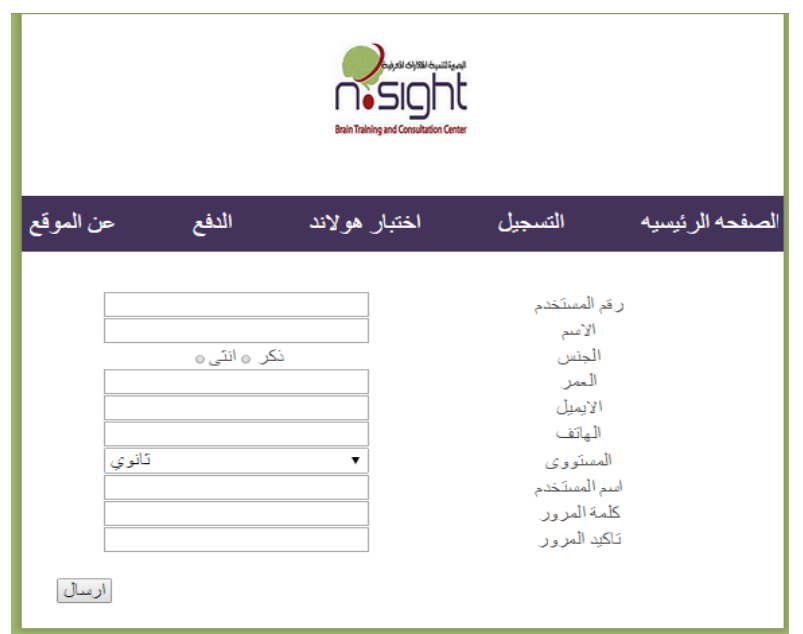

Figure 2: sign-up

\section{Holland test page:}

This page includes the test, and displays thirty-four questions with two possible yes or no answers and the student then must move to the next two pages to complete the test (see Figure $3)$.

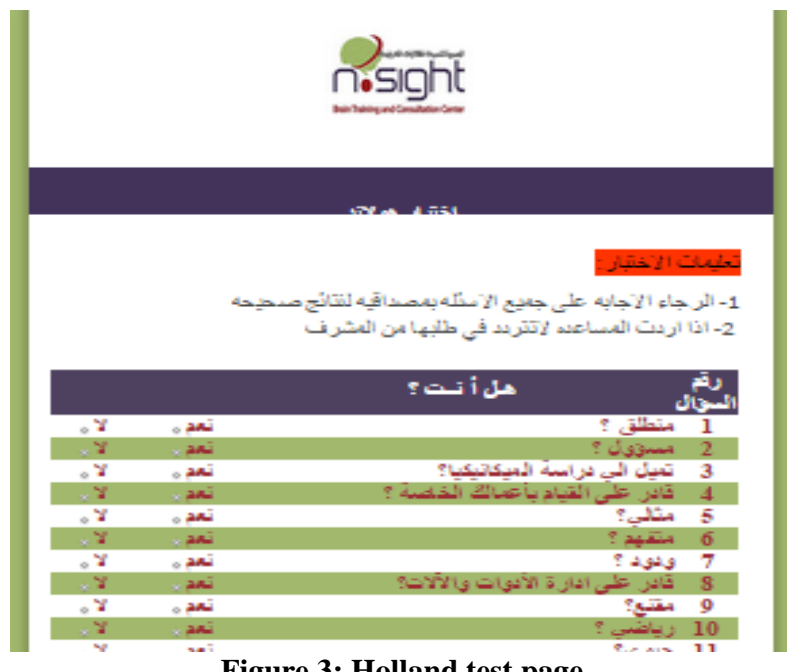

Figure 3: Holland test page

\section{Report page:}

After answering all 106 questions, the system then calculates how many yes and no responses there are. Yes is measured as degree 1 and no as degree 0 , and then each was put in its specific personality type. The report page contains the users' information and the test results, with the table containing each type, its degree, and presented as a pie chart. The Holland code is shown which consisted of the highest three types , and following this the student is told what their suitable career is according to his Holland code (see Figures 4-5).

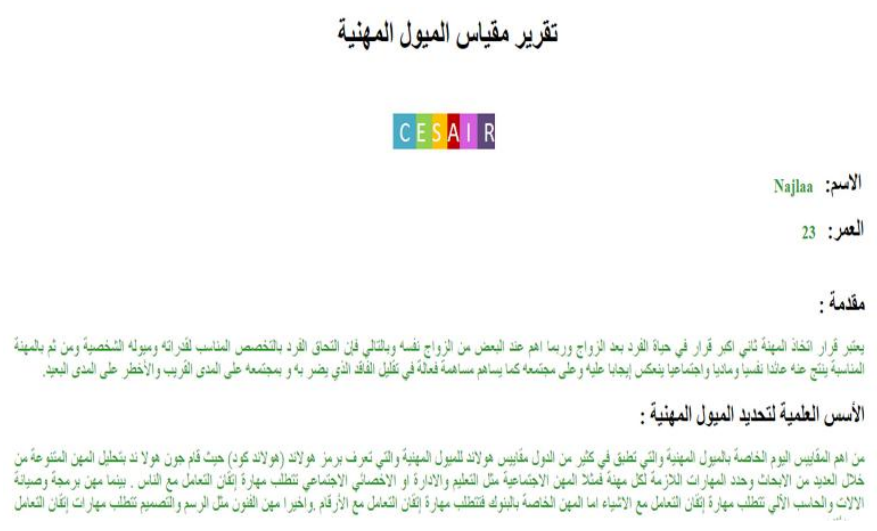

Figure 4: Report page (1)

\begin{tabular}{|c|c|c|}
\hline |لارجة & |لرمز & الثنط \\
\hline 18 & $\mathrm{~S}$ & الاجنماعي \\
\hline 17 & $\mathrm{E}$ & المغامز \\
\hline 16 & I & المنتكنف \\
\hline 15 & $\mathrm{R}$ & الو اقعي \\
\hline 13 & C & الثقلتدي \\
\hline 12 & A & الفني \\
\hline
\end{tabular}

Figure 5: Report page (2)

\section{RESULT}

The results based on the three highest means of categories are the clusters in which students have the most interest, and their corresponding labels are his/her Holland code. The three highest means of categories for students of information systems are social (mean of correct answers $=12.79, \mathrm{SD}=$ 2.86 ), artistic (mean of correct answers $=11.29, \mathrm{SD}=2.16$ ) and investigative (mean of correct answers $=11.11, \mathrm{SD}=$ 2.67). The three highest Holland codes of IS students was "SAC". The three highest means of categories for students of computer science are social (mean of correct answers $=13.67$, $\mathrm{SD}=2.76$ ), investigative (mean of correct answers $=13.22$, $\mathrm{SD}=2.56$ ) and conventional (Mean of correct answers = 12.74, SD = 2.18). The three highest Holland codes of CS students was "SIC". See table 2

Table2 :Group Statistics

\begin{tabular}{|ll|r|r|r|c|}
\hline & Major & $\mathrm{N}$ & \multicolumn{1}{|c|}{ Mean } & Std. Deviation & $\begin{array}{c}\text { Std. Error } \\
\text { Mean }\end{array}$ \\
\hline Artistic & CS & 27 & 11.5556 & 3.02977 & .58308 \\
& IS & 28 & 11.2857 & 2.15780 & .40779 \\
\hline Convntional & CS & 27 & 12.7407 & 2.17667 & .41890 \\
& IS & 28 & 10.3571 & 3.49830 & .66112 \\
\hline Investigative & CS & 27 & 13.2222 & 2.56205 & .49307 \\
& IS & 28 & 11.1071 & 2.67137 & .50484 \\
\hline Enterprising & CS & 27 & 12.1852 & 3.63780 & .70010 \\
& IS & 28 & 10.9643 & 3.09698 & .58527 \\
\hline Realistic & CS & 27 & 11.4444 & 3.23839 & .62323 \\
& IS & 28 & 11.0357 & 2.45677 & .46429 \\
\hline Social & CS & 27 & 13.6667 & 2.75960 & .53109 \\
& IS & 28 & 12.7857 & 2.85913 & .54032 \\
\hline
\end{tabular}


Based on the independent sample, test analyses performed on the Holland questionnaire are a series six broad personality type categories between students of information systems and computer science. Table $3 \mathrm{P}=.004$. $004<0.05$ for conventional and investigative indicates that students of information systems and computer science are different in the conventional and investigative elements but share some similarity in the other broad personality categories - realistic, artistic, social, and enterprising. See table 3references (2), (3) are each numbered with separate brackets (1)-(3). Please note that the references at the end of this document are in the preferred referencing style. Please ensure that the provided references are complete with all the details and also cited inside the manuscript (example: page numbers, year of publication, publisher's name etc.).

Table 3:Independent Samples Test

\begin{tabular}{|c|c|c|c|c|c|c|c|c|c|c|}
\hline & \multicolumn{2}{|c|}{$\begin{array}{l}\text { Levene's Test for } \\
\text { Equality of Variances }\end{array}$} & \multicolumn{7}{|c|}{ t-test for Equality of Means } \\
\hline & & \multirow[b]{2}{*}{$\mathrm{F}$} & \multirow[b]{2}{*}{ Sig. } & \multirow[b]{2}{*}{$t$} & \multirow[b]{2}{*}{ df } & \multirow[b]{2}{*}{ Sig. (2-tailed) } & \multirow{2}{*}{$\begin{array}{c}\text { Mean } \\
\text { Diff erence }\end{array}$} & \multirow{2}{*}{$\begin{array}{l}\text { Std. Error } \\
\text { Diff erence }\end{array}$} & \multicolumn{2}{|c|}{$\begin{array}{l}95 \% \text { Confidence } \\
\text { Interval of the } \\
\text { Diff erence }\end{array}$} \\
\hline & & & & & & & & & Lower & Upper \\
\hline Artistic & $\begin{array}{l}\text { Equal variances } \\
\text { assumed }\end{array}$ & 4.733 & .034 & .382 & 53 & .704 & .26984 & .70723 & -1.14868 & 1.68836 \\
\hline & $\begin{array}{l}\text { Equal variances } \\
\text { not assumed }\end{array}$ & & & .379 & 46.859 & .706 & .26984 & .71153 & -1.16168 & 1.70136 \\
\hline Conv ntional & $\begin{array}{l}\text { Equal variances } \\
\text { assumed }\end{array}$ & 6.446 & .014 & 3.021 & 53 & .004 & 2.38360 & .78909 & .80089 & 3.96631 \\
\hline & $\begin{array}{l}\text { Equal variances } \\
\text { not assumed }\end{array}$ & & & 3.046 & 45.428 & .004 & 2.38360 & .78266 & .80766 & 3.95954 \\
\hline Investigative & $\begin{array}{l}\text { Equal variances } \\
\text { assumed }\end{array}$ & .014 & .907 & 2.995 & 53 & .004 & 2.11508 & .70622 & .69857 & 3.53158 \\
\hline & $\begin{array}{l}\text { Equal variances } \\
\text { not assumed }\end{array}$ & & & 2.997 & 52.999 & .004 & 2.11508 & .70568 & .69967 & 3.53049 \\
\hline Enterprising & $\begin{array}{l}\text { Equal variances } \\
\text { assumed }\end{array}$ & .070 & .793 & 1.342 & 53 & .185 & 1.22090 & .90982 & -.60397 & 3.04577 \\
\hline & $\begin{array}{l}\text { Equal variances } \\
\text { not assumed }\end{array}$ & & & 1.338 & 51.036 & .187 & 1.22090 & .91251 & -.61101 & 3.05281 \\
\hline Realistic & $\begin{array}{l}\text { Equal variances } \\
\text { assumed }\end{array}$ & 1.515 & .224 & .529 & 53 & .599 & .40873 & .77329 & -1.14229 & 1.95975 \\
\hline & $\begin{array}{l}\text { Equal variances } \\
\text { not assumed }\end{array}$ & & & .526 & 48.486 & .601 & .40873 & .77716 & -1.15345 & 1.97091 \\
\hline Social & $\begin{array}{l}\text { Equal variances } \\
\text { assumed }\end{array}$ & .045 & .834 & 1.162 & 53 & .250 & .88095 & .75813 & -.63966 & 2.40156 \\
\hline & $\begin{array}{l}\text { Equal variances } \\
\text { not assumed }\end{array}$ & & & 1.163 & 53.000 & .250 & .88095 & .75763 & -.63866 & 2.40056 \\
\hline
\end{tabular}

\section{DISCUSSION}

This study handles many important issues regarding the results of the Holland test and can help students to identify the cluster(s) of career in which they would have the most interest and satisfaction.

In discussing the results cited in tables 2 and 3 the following themes were evident:

1. The three highest means of categories for students of computer science are social, investigative and conventional. The three highest Holland codes of CS students were "SIC".

2. The three highest means of categories for students of information systems are social, artistic and investigative. The three highest Holland codes of IS students was "SAC".

3. The personality type categories between students of information systems and computer science are different in conventional and investigative but similar in the other broad personality type categories - realistic, artistic, social, and enterprising.

4. Suitable careers for CS students who were highest in the SIC code: General practitioner, psychologist, technical and computer engineering, working in the human resources department, in the medical field or a laboratory technician.

5. Suitable careers for IS students who were highest in the SAC code: architecture, the medical field, nurse, specialist social worker or other social service position, or computer engineering.

A few students may present with contrasting interests, and as Holland explains, contrasting interests in the model do not share much in common and often have pursuits that are truly opposite each other. A student with such a contrast in their Holland result presents a difficulty in sourcing the career that adequately reflects this, simply because it is not easy finding a job that contains such opposing attributes. If we look at the computer studies undergraduates showing an IC code, we see that this does not suggest any particular career (Figure 1).

If a student does not find many careers that fit their Holland code, the code can supplement this index with careers that contain perhaps only one of their attributes, and this is achieved in numerous ways. One way is for the graduate to identify an alternative in which to satisfy their requirements by distinguishing between career activity and personal or pleasure activity. In other words, they can have a career that suits one of their characteristics but have fun in their personal life in a way that fits a different characteristic. A much less 
common situation is where a graduate finds a career which fits one side of their code but is conducted within the workplace of a different one.

\section{CONCLUSION}

This paper discussed the Holland test that arose from observations indicating that some students have difficulty in determining their suitable career. As this affects their performance, productivity and satisfaction, it remains important to understand how finding a career that fits their personality and the results may be useful by evaluating their problem in order to determine the suitable career according to six personality types of Holland theory. This paper compared personality types of females IS student with the personality types of CS student in Saudi Arabia.

The future work for this study is to apply the Arabic version of the Holland test on males student to compare personality types of females student with the personality types of males student in Saudi Arabia.

\section{REFERENCES}

[1] Cruickshank, C. S. (2005). A Test of Holland's Congruence Assumption Using Four-Year Public College Students in Ohio. Ohio: the University of Toledo.

[2] Parsons, F. (1909). Choosing A Vocation. London: MEYER BLOOMFIELD.

[3] McCoy, T. A. (2004). Vocational Identity Among Transfer Students A Descriptive Study The Using My Vocational Situation Instrument. United States: University of Maryland.

[4] Quenk, N. L. (2009). Essentials of Myers-Briggs Type
Indicator Assessment. United States of America: John Wiley \& Sons, Inc.

[5] Mi-Ran1, K., \& Su-Jeong, H. (2014). The Characteristics of the Myers-Briggs Type Indicator in Nursing Students.

[6] Timothy C. Thomason, E. (1999). Basics of Career Development. American Indian Rehabilitation Research and Training Centre, 95.

[7] Hughes, B. (2013). Retrieved from The Herrmann Brain Dominance Instrument website http://www.hbdi.com/uploads/100046_Brochures/10067 8.pdf

[8] Herrmann, N. (1999). The Theory behind the HBDI and Whole Brain Technology. Retrieved from hbdi.com: http://www.hbdi.com/home/friendlyDownload.cfm?direc tory $=100024 \_$articles\&actualFile $=100543$.pdf\&saveNam $\mathrm{e}=$ Theory-Behind-The-HBDI.pdf.

[9] Bawaneh, A. K., Abdullah, A.-G. K., Saleh, S., \& YinYin, K. (2011). JORDANIAN STUDENTS' THINKING STYLES BASED ON HERRMANN WHOLE BRAIN MODEL. International Journal of Humanities and Social Science, 89-97.

[10] Ruff, E. A., Reardon, R. C., \& Bertoch, S. C. (2007). Creating A Research Database On Holland's Theory And Practical. Florida: The Florida State University.

[11] Miller, M. J. (1994). A "Circuitous" Test of Holland's Theory. JOURNAL OF EMPLOYMENT COUNSELLING, 137-143.

[12] John, H. L. (1997). Making Vocational Choices: A Theory of Vocational Personalities and Work Environments. Lutz Florida. 